\title{
Factors Influencing Public Employee Engagement and Its Impact on Organizational Performance*
}

\author{
Chulwoo Kim**
}

\begin{abstract}
The purpose of this study was to explore the factors influencing employee engagement and its possible outcomes. Using data from a large-scale survey of employees in 72 US federal government agencies, and several organizational factors in public setting as control variables, the study empirically tested three contextual factors (participative leadership support, organizational fairness, and supportiveness of organizational context) that influence employee engagement in federal agencies. The study also examined the mediating role of employee engagement between the three contextual variables and organizational performance. The results indicate that participative leadership support and supportiveness of organizational context predict employee engagement. In addition, employee engagement mediated the relationship between antecedents and organizational performance.
\end{abstract}

Keywords: employee engagement, organizational performance, US federal agencies

\section{INTRODUCTION}

As intangible assets such as skills, knowledge, and values have become more critical to organizational success, how to motivate employees with these assets has become the primary interest of organizations to create better outcomes. Public organizations also need more actively involved employees to address complicated challenges such as globalization, devolution, rapid technological change, resource scarcity, and rising

* The author thanks the managing editor and two anonymous reviewers for their constructive advice and suggestions for improving this article.

** Chulwoo Kim has a PhD in public administration from the School of Public Affairs and Administration at Rutgers, the State University of New Jersey. He is currently a visiting research fellow at the Korea Institute of Public Administration. His research interests include organizational behavior, organizational management, performance management, human resource management, and research methods. E-mail: cwkim@kipa.re.kr.

Manuscript received October 24, 2011; out for review October 26, 2011; review completed December 9, 2011; accepted December 15, 2011.

The Korean Journal of Policy Studies, Vol. 26, No. 3 (2011), pp. 69-90.

(C) 2011 by the GSPA, Seoul National University 
organizational interdependencies (Thomson \& Perry, 2006). As a result, increased attention has been paid in recent years to employee engagement, especially among practitioners and consultants. The main reason is its linkage to positive organizational outcomes (Harter, Schmidt, \& Hayes, 2002; Saks, 2006; Ott, 2007; Gallup Organization, 2008; US MSPB, 2008). Despite this growing interest, not enough empirical studies have been performed on the driving factors that may influence employee engagement.

This study explores the organizational factors that influence employee engagement in federal agencies, as well as the impact of employee engagement on job performance. First, employee engagement and related concepts are introduced and defined. Second, three variables that may determine employee engagement in federal agencies are explained, and hypotheses regarding their influence are introduced. After that, the effects of employee engagement on perceived organizational performance are discussed. Regression analysis results are then described, followed by discussion of their implications.

\section{THEORETICAL BACKGROUND AND FRAMEWORK}

According to Kahn, who introduced the concept, employee engagement can be defined as 'the harnessing of organization members' selves to their work roles: in engagement, people employ and express themselves physically, cognitively, and emotionally during role performances" (Kahn, 1990, p. 694). By definition, engagement includes multifaceted (physical, cognitive, and emotional) involvement in the job, whereas job involvement solely focuses on cognition or beliefs (Kanungo, 1982). Organizational commitment can be considered part of employee engagement, because it deals only with employees' attitudes (Saks, 2006; Robinson, Perryman, \& Hayday, 2004) whereas engagement includes both rational and emotional commitment (US MSPB, 2008). Robinson, Perryman, \& Hayday (2004, p. 10) therefore regard engagement as "one step up from commitment" or "commitment plus" and defined it as follows:

Engagement is a positive attitude held by the employee towards the organization and its value. An engaged employee is aware of business context, and works with colleagues to improve performance within the job for the benefit of the organization. The organization must work to nurture, maintain and grow engagement, which require a two-way relationship between employees. (Robinson, Perryman, \& Hayday, 2004, p. 9) 
Based on the definition above, engagement is formal behavior including interaction with the organization. Organizational citizenship behavior has some similarities with engagement but has been defined as individual and informal behavior not recognized by the official reward system (Organ, 1988). Simply put, engagement is directly related to better performance for the organization. The definition given in a recent report by the US Merit Systems Protection Board also supports those given in previous studies: "Employees who are engaged have some type of heightened connection to their work, their organization, or the people they work for or with that cause them to produce better results for the organization" (US MSPB, 2008, p. 2).

In sum, the concept of engagement theory some elements with similar constructs such as commitment and organizational citizenship behavior, but does have exclusive and critical elements, such as voluntary and discretionary behavior, that directly relate to performing organizational roles.

\section{Antecedents of Employee Engagement}

Early management theories, such as Maslow's five levels of needs (1943) and Herzberg's motivation-hygiene theory (Herzberg, Mausner, \& Snyderman, 1959) provide meaningful insights into factors that motivate employees. However, they do not fully explain why certain factors cause different degrees of cognitive, emotional, and physical employee engagement that affect organizational performance. According to Saks (2006), social exchange theory (SET) provides a strong theoretical explanation for the degree of employee engagement in organizations. The main argument of SET is that "obligations are generated through a series of interactions between parties who are in a state of reciprocal interdependence" (Kular, Gatenby, Rees, Soane, \& Trus, 2008, p. 5). According to SET, employees choose to engage themselves to varying degrees and in response to the economic and socioeconomic resources received from their organization. In other words, when the organization does not provide these resources, employees will not devote cognitive, emotional, and physical resources to the job performance but will withdraw and disengage themselves from their roles.

Cropanzano and Mitchell (2005) reviewed several models developed by researchers based on social exchange relationships in work settings. The models include perceived organizational support, support to commitment, team support, supervisory support, and trust. The models suggest that employees may return the benefits they receive in a social exchange relationship from their supervisors, coworkers, and organizations. 


\section{Hypotheses}

Studies have suggested several antecedent factors for employee engagement. Robinson, Perryman, and Hayday (2004) found recognition and performance and development opportunity to be the most significant factors influencing engagement, and work characteristics and leadership to be the most significant threats. Perceived organizational support, job characteristics, and procedural fairness predict engagement as well (Saks, 2006). Similarly, the US Merit Systems Protection Board (2008) found six factors to be critical for engaging federal employees: (1) pride in one's work or workplace, (2) satisfaction with leadership, (3) opportunity to perform well at work, (4) satisfaction with the recognition received, (5) prospect for future personal and professional growth, and (6) a positive work environment with some focus on teamwork. Based on previous literature and empirical findings, this study considered leadership support, organizational fairness, and supportiveness of organizational context as antecedent factors that shape organizational culture and influence employee engagement.

Empowerment and delegation can motivate employees by addressing their higher needs. The degree of empowerment can increase employees' self efficacy so that they may have more confidence in their performance. And such attitudes will cause employees to make their best efforts, which leads to better organizational performance (Conger \& Kanungo, 1988; McCaffrey, Faerman, \& Hart, 1995; Bowen \& Lawler, 1995).

According to Daft (2010), employees' ability to be fully engaged depends upon their leader's behavior. He said the leader's role is to organize a system in which employees can learn, contribute, and develop. Tannenbaum and Schmidt (1958) noted that a leader's choice of decision procedures reflects forces in the leader, in the subordinates, and in the situation. And successful leaders are those who are aware of these forces and behave appropriately at any given time. Level of participation is the key measurement of leadership support. The level of participation can be measured based on two criteria: level of delegation, and empowerment. Delegation means how much responsibility leaders delegate to subordinates, and empowerment indicates how much people actually feel empowered by the leadership and decision processes.

A qualitative study with 31 participants from various industries concluded that employee behaviors are partly dependent on leadership style in their organization (Carsten, Uhl-Bien, West, Patera, \& McGregor, 2010). This study found that employees with empowering leadership were more likely to be proactive and participative. Therefore, a positive relationship may be inferred between participative leadership support and employee engagement. 
Hypothesis 1: Public organizations with higher levels of participative leadership support will have higher levels of employee engagement.

On the other hand, Robbins (2001) argued that many people do not want the additional responsibility and increased stress that accompany empowerment opportunities. As a result, empowerment opportunities provided by leaders may not always lead to employee engagement. He said proper organizational culture (trust, risk taking, participation) within a supportive system (training and resources) can be a necessary condition when linking empowerment to productivity.

Organizational support indicates how employees perceive the work environment and developmental opportunities afforded them (Hollensbe, Khazanchi, \& Masterson, 2008). Supportiveness of organizational context includes a perception of adequate rewards, information, and education systems (Edmondson, 2004). Eisenberger, Huntington, Hutchison, and Sowa (1986) pointed out the importance of employees' social exchange relationships with perceived organizational support. Rich, Lepine, and Crawford (2010) also found perceived organizational support increases employees' willingness to engage fully in work roles. We can infer that supportiveness of organizational context is related to followers' attitudes, behavior, and performance, but no research has tested these relationships.

Hypothesis 2: Public organizations with higher levels of supportiveness of organizational context will have higher levels of employee engagement.

According to the equity model (Adams, 1963), individuals are motivated by how fairly they are treated in comparison with others. Individuals assign the two variables, inputs and outcomes, with different weights based on their perception of the situation. Perceived equitable levels may encourage employees to change their actions on inputs and/or outputs. Beside equity or inequity between outcomes and inputs, employees' assessments of procedural fairness may also be related to attitudes such as intention to leave the organization, willingness to steal from the company, and job satisfaction. Employees who have been treated fairly and are satisfied are more likely to produce positive outcomes. As stated in the discussion of SET above, most people desire to have fair exchanges with their coworkers and organization. And fairly treated employees are more likely to give something back to the organization (Hellriegel \& Slocum, 2007).

Two dimensions from organizational fairness (also known as organization justice) studies will also be used as antecedent variables. Distributive fairness means employee outcomes (such as equity and equality) are perceived as fair. Procedural fairness 
indicates employees perceive procedures as fair using seven decision rules: consistency (across persons and over time), bias suppression, accuracy of information, correctability of wrong decisions, ethicality, voice, and decision control (Leventhal, 1980; Thibaut \& Walker, 1975; Colquitt, 2001). Research on organizational fairness has established that fairness perceptions may influence the behaviors and attitudes of employees (Colquitt, Conlon, Wesson, Porter, \& Ng, 2001). Employees who feel that they are treated fairly tend to engage more actively with a group or an organization (Rubin, 2007).

Hypothesis 3: Public organizations with higher levels of procedural fairness will have higher levels of employee engagement.

Hypothesis 4: Public organizations with higher levels of distributive fairness will have higher levels of employee engagement.

Table 1. Previous Studies on Outcomes of Employee Engagement

\begin{tabular}{l|l}
\hline \multicolumn{1}{c|}{ Authors } & \multicolumn{1}{c}{ Outcomes } \\
\hline Harter, Schmidt, \& Hayes (2002) & $\begin{array}{l}\text { Better customer satisfaction } \\
\text { Customer loyalty rating improvement } \\
\text { Increase in profitability } \\
\text { Productivity improvement } \\
\text { Decrease in employee turnover } \\
\text { Increase in employee safety }\end{array}$ \\
\hline Sonnentag (2003) & Positive effect on proactive behavior1 \\
\hline Schaufeli \& Bakker (2004) & Less turnover intention \\
\hline Saks (2006) & $\begin{array}{l}\text { Improved job satisfaction } \\
\text { Improved organizational commitment } \\
\text { Less intention to quit } \\
\text { Improved organizational citizenship behavior }\end{array}$ \\
\hline Ott (2007) & Higher earnings per share among publicly traded businesses \\
\hline & $\begin{array}{l}\text { Higher score in agency results as measured by the Office of M anagement and } \\
\text { Budget's Program Assessment Rating Tool } \\
\text { Substantial decrease in employee's intent to leave the agency } \\
\text { Less use of sick leave } \\
\text { US M erit Systems Protection } \\
\text { Board (2008) }\end{array}$ \\
\hline Less work time lost to work-related injury or illness \\
\hline Rich, Lepine, \& Craw ford (2010) & $\begin{array}{l}\text { Increase in Task performance } \\
\text { Improved organizational citizenship behavior }\end{array}$ \\
\hline
\end{tabular}

1. Crant (2000, p.436) defined proactive behavior as "taking initiative in improving current circumstances or creating new ones; it involves challenging the status quo rather than passively adapting to present conditions" 
Compare to influencing factors, relatively many studies have been performed on the outcomes of employee engagement. Table 1 summarizes earlier findings on the various consequences of employee engagement. Therefore, employee engagement will be related to organizational performance as follows:

Hypothesis 5: Higher levels of employee engagement in public organizations will result in higher levels of organizational performance.

Based on the studies discussed above, it is possible to infer that employee engagement has a positive effect on organizational performance. Furthermore, several studies have shown the mediating role of employee engagement between various antecedents and organizational performance (Rich, Lepine, \& Crawford, 2010; Saks, 2006; Schaufeli $\&$ Bakker, 2004; Sonnentag, 2003). Therefore:

Hypothesis 6: Employee engagement in public organizations will mediate the relationship between the antecedents and organizational performance.

\section{DATA AND METHODOLOGY}

The unit of analysis for this study is US federal agencies. Federal agencies in the United States consist of executive departments, staff organizations, independent agencies, and government-owned corporations. Since employee engagement is required for everyone in the organization irrespective of managerial level, the antecedents of employee engagement are considered an aggregated response of employees in federal agencies. In a similar vein, antecedent variables such as participative leadership support, fairness, and supportiveness of organizational context are also measured at the individual level, but will be considered as the combined effects of multiple individuals.

\section{Data Sources and Sample}

Data from the 2008 Federal Human Capital Survey (FHCS), administered by the Office of Personnel Management, are analyzed. The survey was distributed to employees from major federal agencies represented on the President's Management Council and 54 smaller, independent agencies. The objective of the survey was to see federal employees' perceptions of the degree of workforce management effectiveness. A random sample of 417,128 employees was selected to respond to the survey; 212,223 completed the survey for a response rate of 51 percent. The format was a self-adminis- 
tered Web survey, but paper versions were also available (US OPM, 2008). Of the 212,223 participants, 48.0 percent were female, 44.3 percent had leadership positions (team leader, supervisor, manager, or executive), and 72 percent were white.

This study measured employee engagement and some antecedent variables by selecting questions that showed consistency with measures from previous research. Tables in the appendix list the questions and response options for antecedent, employee engagement, and control variables. In addition, information from the Central Personnel Data File (CPDF), also published by the Office of Personnel Management, which contains demographic and job information for the federal workforce, was used for agencylevel control variables.

\section{Variables}

Three questions from FHCS that showed consistency with previous research were selected to measure employee engagement. The questions asked whether employees were engaged and focused on achieving the results expected of them. In this research, employee engagement is considered as multiple individuals' perceptions of their relationships with co-workers, and informal emergent structures or systems, such as goals, in organizations that reflect the combined effects of local interactions (Marion \& Uhl-Bien, 2001; Lord, 2008).

The measures of participative leadership support were level of delegation and perceived empowerment. Level of delegation was measured based on the degree to which leaders give subordinates opportunities to use their leadership ability. However, as Strauss (1977) pointed out, overt procedures and actual influence can be different in decision procedures. In other words, how much subordinates perceive that they are involved in decision procedures can show the actual level of delegation. The second question, therefore, asks whether subordinates are satisfied with their involvement in decision procedures.

Perceived empowerment of employees by their leadership, the second measure of participative leadership support, has only one question, but it directly asks about the degree of empowerment. Therefore, construct validity and reliability issues can be addressed (see Wanous \& Reichers, 1996).

Organizational performance is the dependent variable in this research. It would be ideal if objective performance data were available, but studies have shown that there is a positive correlation between perceived and objective measures of organizational performance (Dollinger \& Golden, 1992; McCracken, McIlwain, \& Fottler, 2001; Powell, 1992; Venkatraman \& Ramanujam, 1987). The important point is not to rely on one narrow criterion. Brewer and Selden (2000) measured organizational performance 
both internally and externally with three values: efficiency, effectiveness, and fairness. They found that narrow measures of performance can yield misleading results on organizational effectiveness (Brewer \& Selden, 2000). Kim (2004), using these concepts of organizational performance, did empirical research and found a relationship between individual-level perception factors and organizational performance. In this study, performance was measured using four survey questions regarding productivity, work quality, customer service orientation, and managerial effectiveness.

Six control variables were also included (policy responsibility, institutional location, organizational tenure, organizational size, organizational age, and task professionalization) to control for agency-level influences. The original measure that this study used for classifying federal agencies into three policy responsibilities was derived from Noll (1985) and from the 2008 Congressional Quarterly's Federal Regulatory Directory. Among 76 agencies that participated in the FHCS, three agencies (Federal Energy Regulatory Commission, National Indian Gaming Commission, and Postal Regulatory Commission) as well as the small independent agencies were dropped because the CPDF data were not available. As a result, 72 federal agencies in the executive branch and independent agencies were studied. The appendix lists measures of antecedent and control variables.

\section{Reliability and Validity Test of the Measures}

The descriptive statistics of variables using FHCS questionnaires and the value of Cronbach's coefficient alpha were analyzed. Table 2 summarizes the result. The lowest mean score was for question 27 (mean $=2.79$; $\mathrm{SD}=1.17$ ), which asked about the federal agency's organizational fairness regarding pay raises and employee performance. The highest mean score was for question 10 (mean $=4.22 ; \mathrm{SD}=0.79)$, which asked about the agency's overall perceived performance. Its mean score is apparently higher than those of the other three items measuring the same construct of organizational performance. One reason might be that the phrase "how would you rate the overall quality of work done by your work group?" is much more subjective than other items asking respondents to assess their work group's performance relative to the performance of others in the same agency. To measure the internal consistency or reliability of the variables, Cronbach's alpha was used. All except two variables had alpha values higher than 0.70 , which is considered adequate reliability (higher than 0.80 is considered good) (Acock, 2008). The variable of employee engagement has an alpha value higher than 0.60 , which is considered acceptable. Therefore, most measurements are reliable or internally consistent.

Since most measures derived from FHCS data were based on more than one survey 
Table 2. Cronbach Coefficient Alpha of M easures in FHCS (M inimum =1, M aximum =5)

\begin{tabular}{|c|c|c|c|c|c|}
\hline Variables & Question & $\mathrm{N}$ & M ean & Standard deviation & Cronbach's alpha \\
\hline Employee engagement & $\begin{array}{r}1 \\
19 \\
33\end{array}$ & $\begin{array}{l}212,197 \\
211,191 \\
210,685\end{array}$ & $\begin{array}{l}4.09 \\
4.12 \\
4.06\end{array}$ & $\begin{array}{l}0.86 \\
0.83 \\
0.77\end{array}$ & 0.61 \\
\hline Participative leadership & $\begin{array}{l}13 \\
24 \\
55\end{array}$ & $\begin{array}{l}210,422 \\
207,182 \\
212,188\end{array}$ & $\begin{array}{l}3.62 \\
3.24 \\
3.42\end{array}$ & $\begin{array}{l}1.10 \\
1.08 \\
1.11\end{array}$ & 0.83 \\
\hline $\begin{array}{l}\text { Supportiveness of } \\
\text { organizational context }\end{array}$ & $\begin{array}{r}2 \\
3 \\
16 \\
18 \\
50 \\
51 \\
\end{array}$ & $\begin{array}{l}212,195 \\
212,194 \\
210,688 \\
210,517 \\
208,409 \\
208,925\end{array}$ & $\begin{array}{l}3.65 \\
3.80 \\
3.19 \\
3.54 \\
3.99 \\
3.36\end{array}$ & $\begin{array}{l}1.10 \\
0.93 \\
1.22 \\
1.15 \\
0.88 \\
1.08 \\
\end{array}$ & 0.82 \\
\hline Procedural fairness & $\begin{array}{l}22 \\
23 \\
44 \\
45 \\
46 \\
47\end{array}$ & $\begin{array}{l}202,039 \\
196,682 \\
182,715 \\
195,342 \\
191,535 \\
193,586\end{array}$ & $\begin{array}{l}3.07 \\
2.89 \\
3.29 \\
3.42 \\
3.77 \\
3.46 \\
\end{array}$ & $\begin{array}{l}1.22 \\
1.16 \\
1.14 \\
1.20 \\
1.08 \\
1.18 \\
\end{array}$ & 0.90 \\
\hline Distributive fairness & $\begin{array}{l}27 \\
28 \\
29 \\
30\end{array}$ & $\begin{array}{l}200,807 \\
202,707 \\
202,095 \\
208,232\end{array}$ & $\begin{array}{l}2.79 \\
3.20 \\
2.98 \\
3.60\end{array}$ & $\begin{array}{l}1.17 \\
1.21 \\
1.14 \\
1.11\end{array}$ & 0.87 \\
\hline Organizational performance & $\begin{array}{r}9 \\
10 \\
14 \\
25\end{array}$ & $\begin{array}{l}212,189 \\
212,190 \\
206,229 \\
207,612\end{array}$ & $\begin{array}{l}3.84 \\
4.22 \\
3.27 \\
3.30\end{array}$ & $\begin{array}{l}1.12 \\
0.79 \\
1.12 \\
1.17\end{array}$ & 0.77 \\
\hline
\end{tabular}

question, each measure was developed by using principal component factor analysis, rotated through varimax rotation. Factor loadings, which are the correlation coefficients between the variables and factors, ranged from 0.61 to 0.91 . Questions 50 and 16 on supportiveness of organizational context had the first $(0.61)$ and second $(0.63)$ lowest factor loadings. In social science, the cutoff value for factor loadings generally depends on the situation (Dunteman, 1989). Hence, for Likert scales, loadings above 0.6 are considered high and those below 0.4 are considered low (Garson, 2010; Hair, Anderson, Tatham, \& Black, 1998). Therefore, it can be concluded that the variables are highly correlated with the factors.

Communality refers to the total percent of the variance in a variable explained by all factors together. Communality of a variable is computed by the sum of the squared factor loadings for that variable. A communality value above 0.6 is high, and 0.5 is acceptable (MacCallum, Widaman, Zhang, \& Hong, 1999). In our analysis, uniqueness, which is the opposite of communality, is used instead. High uniqueness signifies that 
a variable is not fully explained by existing factors. Two factors in supportiveness of organizational context (question $16=0.61$ and question $50=0.63$ ) are high in uniqueness.

Lastly, variables were tested using the Kaiser-Meyer-Olkin (KMO) measure of sampling adequacy. This measure estimates whether the variables are factor well based on correlation and particle correlation. High KMO values can be interpreted to imply that the variables have many in common and that they are measuring a common factor. To perform factor analysis, KMO statistics should ideally be higher than 0.6 ; above 0.5 is acceptable (Garson, 2010; Kaiser, 1974). All variables had KMO values higher than 0.5.

\section{RESULTS AND FINDINGS}

Table 3 displays the descriptive statistics of the sample. The mean of the agencies' average mean scores for employee engagement is 4.09 , and the standard deviation is 0.07. The Postal Regulatory Commission has the highest average mean score for

Table 3. Descriptive Statistics of the Sample (Agency Level)

\begin{tabular}{|c|c|c|c|c|c|}
\hline & Mean & SD & M inimum & Maximum & Unit \\
\hline Employee engagement & 4.09 & 0.07 & 3.67 & 4.43 & Average mean score \\
\hline Participative leadership & 3.42 & 0.12 & 2.66 & 3.84 & Average mean score \\
\hline Procedural fairness & 3.29 & 0.14 & 2.77 & 3.81 & Average mean score \\
\hline Distributive fairness & 3.15 & 0.12 & 2.67 & 3.71 & Average mean score \\
\hline Organizational support & 3.58 & 0.10 & 2.76 & 4.01 & Average mean score \\
\hline Regulatory policy & 0.15 & 0.36 & 0 & 1 & Dummy variable \\
\hline Distributive policy & 0.13 & 0.33 & 0 & 1 & Dummy variable \\
\hline Redistributive policy & 0.097 & 0.298 & 0 & 1 & Dummy variable \\
\hline Administrative task & 0.53 & 0.22 & 0.14 & 0.89 & $\begin{array}{l}\text { Proportion of employees in administrative } \\
\text { occupations }\end{array}$ \\
\hline Professional task & 0.28 & 0.19 & 0.03 & 0.73 & $\begin{array}{l}\text { Proportion of employees in professional } \\
\text { occupations }\end{array}$ \\
\hline Institutional location & 0.28 & 0.45 & 0 & 1 & $\begin{array}{l}\text { Under the executive branch =1; } \\
\text { independent }=0\end{array}$ \\
\hline Organizational tenure & 15.2 & 2.91 & 8.3 & 24.3 & Average tenure of full-time employees \\
\hline Organizational size & 25,089 & 55,333 & 22 & 253,747 & Number of full-time employees ${ }^{2}$ \\
\hline Organizational age & 1,945 & 51.2 & 1775 & 2002 & Year the agency was established \\
\hline
\end{tabular}

2. In multiple regression models, the organizational size of a federal agency is analyzed by calculating the natural logarithm of the number of full-time employees of the agency 
employee engagement (4.43). On the other hand, with 3.66 in mean score, the InterAmerican Foundation has the lowest average mean score in employee engagement. When comparing two organizational fairness variables, perceived distributive fairness (3.15) has lower levels than procedural fairness (3.29) in the federal agencies. The agency with the highest proportion of employees in professional occupations is Defense Nuclear Facilities Safety Board (0.76) followed by National Aeronautics and Space Administration (0.67). The mean average tenure in federal agencies is 15.2 years, ranging between 8.3 and 24.3 years. The oldest agency (Department of the Army) was established in 1775 and the newest (Department of Homeland Security) in 2002. The agency with the fewest full-time employees is the African Development Foundation with 22 employees. The Department of Veterans Affairs had 253,747 fulltime employees in 2008.

Correlation analysis can show the basic relationships among variables. To verify any potential methodological problems that may influence the results of the analysis, several diagnostic tests were conducted. The analyses of the residuals did not indicate

Table 4. Correlations of Employee Engagement and Antecedents

\begin{tabular}{|c|c|c|c|c|c|c|c|c|c|c|c|c|c|}
\hline & 1 & 2 & 3.1 & 3.2 & 4 & 5.1 & 5.2 & 5.3 & 6.1 & 6.2 & 7 & 8 & 9 \\
\hline \multicolumn{14}{|l|}{$\begin{array}{l}\text { 1. Employee } \\
\text { engagement }\end{array}$} \\
\hline $\begin{array}{l}\text { 2. Participative } \\
\text { leadership }\end{array}$ & $0.85 * * *$ & & & & & & & & & & & & \\
\hline $\begin{array}{l}\text { 3.1. Procedural } \\
\text { faimess }\end{array}$ & $0.73^{* * *}$ & $0.82^{* * *}$ & & & & & & & & & & & \\
\hline $\begin{array}{l}\text { 3.2. Distributive } \\
\text { faimess }\end{array}$ & $0.62 * * *$ & $0.75 * * *$ & $0.69 * * *$ & & & & & & & & & & \\
\hline 4. Supportiveness & $0.71^{* * *}$ & $0.79 * * *$ & $0.61^{* * *}$ & $0.68 * *$ & & & & & & & & & \\
\hline 5.1. Regulatory & -0.02 & 0.05 & -0.01 & -0.09 & 0.15 & & & & & & & & \\
\hline 5.2. Distributive & -0.04 & 0.04 & 0.002 & -0.03 & 0.15 & 0.19 & & & & & & & \\
\hline 5.3. Redistributive & -0.03 & -0.05 & -0.03 & -0.12 & 0.04 & 0.12 & 0.16 & & & & & & \\
\hline $\begin{array}{l}\text { 6.1. Administrative } \\
\text { staff ratio }\end{array}$ & 0.03 & 0.07 & 0.28 & 0.07 & -0.17 & -0.16 & -0.18 & -0.02 & & & & & \\
\hline $\begin{array}{l}\text { 6.2. Professional } \\
\text { staff ratio }\end{array}$ & 0.13 & 0.11 & 0.19 & $0.22^{\dagger}$ & $0.29 *$ & 0.15 & 0.12 & -0.16 & $-0.71 * * *$ & & & & \\
\hline 7. Location & -0.09 & 0.05 & -0.02 & -0.11 & 0.15 & 0.17 & $0.33 *$ & $0.32 * *$ & $-0.20^{\dagger}$ & -0.07 & & & \\
\hline 8. Tenure & -0.04 & -0.08 & -0.18 & -0.05 & 0.03 & 0.05 & -0.16 & $0.23{ }^{\dagger}$ & 0.03 & 0.06 & -0.01 & & \\
\hline 9. Size (In) & -0.04 & 0.08 & -0.04 & -0.18 & $0.266^{\dagger}$ & 0.25 & $0.39 * * *$ & $0.37^{* *}$ & $-0.37 *$ & -0.004 & $0.70^{\text {*** }}$ & 0.02 & \\
\hline 10. Age & 0.005 & -0.07 & -0.02 & 0.12 & -0.10 & -0.23 & -0.18 & $-0.31 * *$ & $0.30^{*}$ & 0.07 & $-0.45 * * *$ & -0.09 & $-0.51 * * *$ \\
\hline
\end{tabular}

$\dagger$ significant at 0.1 level; ** significant at 0.01 level; *** significant at 0.001 level 
major violations of the assumptions of normality, linearity, and absence of influential outliers. No serious problems of multicollinearity or homoscedasticity issues were detected.

To test the hypotheses for the antecedents of employee engagement, multiple regression analysis was performed; table 5 presents the results. The fit of the model was good and statistically significant. Participative leadership support would have a strong positive effect on employee engagement (beta $=0.796, p<0.001$ ), indicating that federal agencies with higher levels of participative leadership support tend to have higher levels of employee engagement. Hypothesis 2 predicted a positive relationship between the supportiveness of the organizational context and employee engagement. The results supported this prediction (beta $=0.24, \mathrm{p}<0.1$ ); higher levels of supportiveness of organizational context in federal agencies lead to higher levels of employee engagement. Procedural fairness did not explain the variation in employee engagement. And contrary to the original hypothesis, distributive fairness was negatively related to employee engagement (beta $=-0.22, \mathrm{p}<0.1$ ). According to the regression analysis, hypotheses 1 and 2 are supported and hypothesis 3 and 4 are not supported.

To test the hypotheses for employee engagement and organizational performance, another multiple regression analysis was conducted; table 6 shows the results. Employee engagement had a strong positive effect on organizational performance (beta $=0.82, \mathrm{p}<0.001$ ). Hypothesis 5 is supported, indicating that federal agencies with higher levels of employee engagement tend to have higher levels of organizational performance.

Finally, hypothesis 6 was tested to see whether employee engagement mediates the relationship between antecedent variables and organizational performance. Three conditions proposed by Baron and Kenny (1986) had to be met for employee engagement

Table 5. M ultiple Regression Analysis of Antecedents of Employee Engagement

\begin{tabular}{l|c|c}
\hline \multirow{2}{*}{} & B & Employee engagement \\
\cline { 2 - 3 } & $0.796^{* * *}$ & 0.14 \\
\hline Participative leadership & $0.24^{\dagger}$ & 0.09 \\
\hline Organizational support & 0.09 & 0.10 \\
\hline Procedural justice & $-0.22^{\dagger}$ & 0.09 \\
\hline Distributive justice & \multicolumn{2}{|c}{0.78} \\
\hline R-squared & \multicolumn{2}{|c}{$75.81^{* * *}$} \\
\hline F & \multicolumn{2}{|c}{72} \\
\hline N & \multicolumn{2}{|c}{} \\
\hline
\end{tabular}

† significant at 0.1 level; $* * *$ significant at 0.001 level 
Table 6. M ultiple Regression Analysis of Employee Engagement and Organizational Performance

\begin{tabular}{l|c|c}
\hline \multirow{2}{*}{} & \multicolumn{2}{|c}{ Organizational performance } \\
\cline { 2 - 3 } & B & SE \\
\hline Employ engagement & $0.82^{* * *}$ & 0.07 \\
\hline Regulatory policy & 0.015 & 0.04 \\
\hline Distributive policy & -0.033 & 0.05 \\
\hline Redistributive policy & -0.024 & 0.05 \\
\hline Administrative task & 0.32 & 0.12 \\
\hline Professional task & $0.32^{* *}$ & 0.13 \\
\hline Institutional location & 0.05 & 0.04 \\
\hline Organizational tenure & -0.08 & 0.005 \\
\hline Organizational size (In) & 0.13 & 0.008 \\
\hline Organizational age & -0.01 & 0.0003 \\
\hline R-squared & \multicolumn{2}{|c}{0.806} \\
\hline $\mathrm{F}$ & \multicolumn{2}{|c}{72} \\
\hline $\mathrm{N}$ & \multicolumn{2}{|c}{} \\
\hline
\end{tabular}

** significant at 0.01 level; *** significant at 0.001 level

to be assumed to be a mediator: (1) the antecedents significantly influence employee engagement; (2) the antecedents significantly affect organizational performance; (3) employee engagement significantly affects organizational performance. If the effect of the antecedents on organizational performance is weaker, employee engagement can be considered to play a mediating role. Using multiple regression analysis, organizational performance was regressed on each antecedent separately to see its effects on organizational performance alone, and consecutively regressed while controlling the effect of employee engagement. The results indicate that the level of coefficients of the antecedents dropped significantly with employee engagement controlled (see

Table 7. M ultiple Regression Analysis of the Mediation Effect of Employee Engagement on Organizational Performance

\begin{tabular}{l|c|c}
\hline & Organizational performance & Employee engagement controlled \\
\cline { 2 - 3 } & $\mathrm{B}$ & $\mathrm{B}$ \\
\hline Participative leadership & $0.87^{* * *}$ & $0.55^{* * *}$ \\
\hline Organizational support & $0.60^{* * *}$ & $0.22^{* * *}$ \\
\hline Procedural justice & $0.78^{* * *}$ & $0.35^{* * *}$ \\
\hline Distributive justice & $0.70^{* * *}$ & $0.31^{* * *}$ \\
\hline
\end{tabular}

*** significant at 0.001 level 
Table 7).

After that, the test proposed by Sobel (1982) was performed to see whether a mediator carried the influence of an independent variable to a dependent variable. For participative leadership support's effect on organizational performance, the mediation effect of employee engagement was statistically significant with approximately 38 percent of the total effect being mediated $(\mathrm{p}<0.001)$. For organizational support, the mediation effect was statistically significant with 63 percent of the total effect mediated ( $\mathrm{p}<0.001)$. And for both procedural fairness and distributive fairness, employee engagement carried the influence of organizational fairness to organizational performance approximately 55 percent $(\mathrm{p}<0.001)$. Thus, the overall mediation effects of employee engagement between antecedents and organizational performance were substantial but partial, indicating that hypothesis 6 is partially supported.

\section{DISCUSSION AND IMPLICATIONS}

The findings on the relationship between the antecedent variables and employee engagement are similar to the findings of earlier studies. Participative leadership support and supportiveness of organizational context had a positive effect on employee engagement as hypothesized. The relationship between employee engagement and organizational performance was positive as well.

In regard to the relations between participative leadership and performance, previous studies have shown mixed conclusions. Some scholars have found substantial positive effects of participative leadership style on performance (Jackson, 1983; Peterson \& Hillkirk, 1991; Bluestone \& Bluestone, 1992). Recent studies, on the other hand, indicate the necessity of mediators to complete the relationship between participative leadership and task performance (e.g., Somech, 2005; Huang, Iun, Liu, \& Gong, 2010). Therefore, based on the analysis results, employee engagement can be a strong mediator between participative leadership and organizational performance.

Two dimensions of organizational fairness did not support the hypotheses. The analysis indicated that procedural fairness had no relationship and distributive fairness did not show a positive relationship with employee engagement. The regression results showed that distributive fairness perceptions significantly but negatively contributed to public employees' engagement: an increase in perceived distributive fairness was related to a decrease in perceived employee engagement. In other words, higher perceived distributive fairness did not lead to more action, so the employees are passive and reactive. Saks (2006) also found a negative effect of distributive fairness on employee engagement in his study surveying 102 employees, but the relationship was 
insignificant.

One possible explanation is that the perception of strong distributive fairness may form an organizational culture that signals that the distribution of resources is fair but also rather fixed. The fact that there is no room to change can diminish the motivation to engage actively. It can also be inferred from the system, especially in federal agencies that are influenced by the distributive fairness perception. When the wage and merit system is wide open and firmly fixed, employee engagement can be lower because employees may think no reward is possible for increased activity and contributions. In fact, due to the "tenuous link between pay and performance in public organizations" (Kurland \& Egan, 1999, p. 442), employees in federal agencies perceived lower levels of distributive fairness (3.15) compared to other factors such as procedural fairness (3.29) and supportiveness of organizational context (3.58). Thus, a financial benefit for public employees in the form of any kind of pay increase is less available, and public managers do not have discretion to set pay directly (Ban, 1995).

As a result, combined effect of low distributive fairness perception among employees and the actual condition of its absence in organizations might lead to lesser valuing of organizational distributive fairness. As a result, as evidenced by their lower distributive fairness perceptions, public employees may have lower engagement because they may not link their efforts directly to appropriate rewards. Furthermore, once employees were familiar with the existing distributive system, they became fully aware of how to beat the system and impress their superiors. As a result, a possible reason for the increased perception of distributive fairness is not that they are satisfied with the payment they receive, but that they are pleased with their workload within the limits of what they can earn. Accordingly, employees may have lower engagement.

A perception of low distributive fairness could also lead to negative employee engagement. One possibility is cynical and negative behaviors. Such employees are not team players and do not support their leaders' decisions without proper cause, which is a downside of follower alienation. On the other hand, employees may also tend to avoid conflict and stick to popular positions without considering the benefits to the group or organization, which is a negative aspect of follower conformism.

The most significant contribution of this study is that it is one of the first comprehensive studies of employee engagement in the context of public organizations. It covered the contextual factors that influence employee engagement, and the mediating role of employee engagement between leadership and organizational performance. The findings on the relationship between the antecedent variables and employee engagement confirm those of earlier studies.

However, since employee engagement is a relatively new concept, there are many interesting areas for future research. For instance, the results reveal some interesting 
findings in regard to relationships between employee engagement and antecedents. Nevertheless, there are still numerous other possible contextual variables such as organizational culture, goal setting, and job ownership that may influence these relationships. Future research should take a careful look at other potential antecedent variables in the federal setting.

In addition, the main data are cross-sectional, which only enables one to see the snapshot of a certain period. Thus, there are still avenues for future research using longitudinal analysis. Although FCHS data have been updated biannually, identifiable individual sources are not provided. However, longitudinal analysis at the agency and sub-agency level are possible. Longitudinal analysis will enable researchers to observe how the antecedents and outcome factors have changed over time.

\section{REFERENCES}

Acock, A. C. 2008. A gentle introduction to Stata (2nd ed.). College Station, TX: Stata Press.

Adams, J. S. 1963. Toward an understanding of inequity. Journal of Abnormal and Social Psychology, 63: 422-436.

Ban, C. 1995. How do public managers manage? Bureaucratic constraints, organizational culture, and the potential for reform. San Francisco, CA: Jossey-Bass.

Baron, R. M., \& Kenny, D. A. 1986. The moderator-mediator variable distinction in social psychological research: Conceptual, strategic, and statistical considerations. Journal of Personality and Social Psychology, 51: 1173-1182.

Bluestone, B., \& Bluestone, I. 1992. Negotiating the future: A labor perspective on American business. New York: Basic Books.

Bowen, D. E., \& Lawler, E. E., III. 1995. Empowering service employees. Sloan Management Review, 36(4): 73-84.

Carsten, M. K., Uhl-Bien, M., West, B. J., Patera, J. L., \& McGregor, R. 2010. Exploring social construction of followership: A qualitative study. Leadership Quarterly, 21: 543-562.

Colquitt, J. A. 2001. On the dimensionality of organizational justice: A construct validation of a measure. Journal of Applied Psychology, 86(3): 386-400.

Colquitt, J. A., Conlon, D. E., Wesson, M. J., Porter, C., \& Ng, K.Y. 2001. Justice at the millennium: A meta-analytic review of 25 years of organizational justice research. Journal of Applied Psychology, 86(3): 425-445.

Conger, J. A., \& Kanungo, R. N. 1988. The empowerment process: Integrating theory and practice. Academy of Management Review, 13: 471-482. 
Congressional Quarterly. 2008. Federal Regulatory Directory (13th ed.). Wahsington DC: Congressional Quarterly Press.

Cropanzano, R., \& Mitchell, M. S. 2005. Social exchange theory: An interdisciplinary review. Journal of Management, 31: 874-900.

Daft, R. L. 2010. The leadership experience (5th ed.). Mason, OH: Thomson Higher Education.

Dollinger, M. J. and Golden, P. A. (1992). Interorganizational and Collective Strategies in Small Firms: Environmental Effects and Performance. Journal of Management, 18: 695-715.

Dunteman, G. H. 1989. Principal components analysis. Thousand Oaks, CA: Sage Publications, Quantitative Applications in the Social Sciences Series, No. 69.

Edmondson, A. C. 2004. Learning from mistakes is easier said than done: Group and organizational influences on the detection and correction of human error. Journal of Applied Behavioral Science, 40(1): 66-90.

Eisenberger, R., Huntington, R., Hutchison, S., \& Sowa, D. 1986. Perceived organizational support. Journal of Applied Psychology, 71: 500-507.

Gallup Organization. 2008. Employee engagement: What's your engagement ratio? Washington, DC: Author.

Garson, G. D. 2010. Statnotes: Topics in multivariate analysis. Retrieved November 7, 2010 from http://www2.chass.ncsu.edu/garson/pa765/statnote.htm.

Hair, J. F., Anderson, R. E., Tatham, R. L., \& Black, W. C. 1998. Multivariate data analysis with readings (5th ed.). Englewood Cliffs, NJ: Prentice-Hall.

Harter, J. K., Schmidt, F. L., \& Hayes, T. L. 2002. Business-unit-level relationship between employee satisfaction, employee engagement, and business outcomes: A meta-analysis. Journal of Applied Psychology, 87(2): 268-279.

Hellriegel, D., \& Slocum, J. W., Jr. 2007. Organizational behavior (11th ed.). Mason, $\mathrm{OH}$ : Thomson Higher Education.

Herzberg, F., Mausner, B., \& Snyderman, B. B. 1959. The motivation to work. New York: John Wiley and Sons.

Hollensbe, E., Khazanchi, S., \& Masterson, S. S. 2008. How do I assess if my supervisor and organization are fair? Identifying the rules and underlying entity-based justice perceptions. Academy of Management Journal, 51(6): 1099-1116.

Huang, X., Iun J., Liu, A., \& Gong Y. 2010. Does participative leadership enhance work performance by inducing empowerment or trust? The differential effects on managerial and non-managerial subordinates. Journal of Organizational Behavior, 31:122-143.

Jackson, S. E. 1983. Participation in decision-making as a strategy for reducing jobrelated strain. Journal of Applied Psychology, 68(1): 3-19. 
Kahn, W. A. 1990. Psychological conditions of personal engagement and disengagement at work. Academy of Management Journal, 33: 692-724.

Kaiser, H. F. 1974. An index of factorial simplicity. Psychomettrika, 39(1): 31-36.

Kanungo, R. N. 1982. Measurement of job and work involvement. Journal of Applied Psychology, 67: 341-349.

Kim, Sangmook. 2004. Individual-Level Factors and Organizational Performance in Government Organizations. Journal of Public Administration Research and Theory, 15(2): 245-261.

Kular, S., Gatenby, M., Rees, C., Soane, E., \& Trus, K. 2008. Employee engagement: A literature review. Kingston-upon-Thames, UK: Kingston Business School. Kingston University Working Paper Series, No. 19.

Kurland, N. B., \& Egan, T. D. 1999. Public v. private perceptions of formalization, outcomes, and justice. Journal of Public Administration Research and Theory, 3: 437-458.

Leventhal, G. 1980. What should be done with equity theory? New approaches to the study of fairness in social relationships. In K. Gergen, M. Greenbers, \& R. Willis (eds.), Social exchange: Advances in theory and research (pp. 27-55). New York: Plenum.

Lord, R. G. 2008. Followers' cognitive and affective structures and leadership process. In R. E. Riggio, I. Chaleff, \& J. Lipman-Blumen (eds.), The art of followership: How great followers create great leaders and organizations. San Francisco, CA: Jossey-Bass.

MacCallum, R. C., Widaman, K. F., Zhang, S., \& Hong, S. 1999. Sample size in factor analysis. Psychological Methods, 4: 84-99.

Marion, R., \& Uhl-Bien, M. 2001. Leadership in complex organizations. Leadership Quarterly, 12(4): 389-419.

Maslow, A.H. 1943. A theory of human motivation. Psychological Review, 50(4): 370-396.

McCaffrey, D. P., Faerman, S. R., \& Hart, D. W. 1995. The appeal and difficulties of participative systems. Organization Science, 6(6): 603-627.

McCracker, M.J. McIlwain, T.F. \& Fottler, M.D. 2001. Measuring Organizational Performance in the Hospital Industry: An Exploratory Comparison of Objective and Subjective Methods. Health Services Management Research,14: 211-219.

Noll, R. G. (ed.) 1985. Regulatory policy and the social sciences. Berkeley, CA: University of California Press.

Organ, D. W. 1988. Organizational citizenship behavior: The good soldier syndrome. Lexington, MA: Lexington Books.

Ott, B. 2007. Investors take note: Engagement boosts earnings. The Gallup Management 
Journal, June 14. Retrieved July 15, 2011 from http://gmj.gallup.com/content /27799/investors-take-note-engagement-boosts-earnings.aspx.

Peterson, D. E., \& Hillkirk, J. 1991. A better idea: Redefining the way American companies work. Boston: Houghton-Mifflin.

Powell, T.C. 1992. Organizational Alignment as Competitive Advantage. Strategic Management Journal, 13: 119-134.

Rich, B. L., Lepine, J. A., \& Crawford, E. R. 2010. Job engagement: Antecedents and effects on job performance. Academy of Management Journal, 53(3): 617-635.

Robbins, S. P. 2001. Organizational behavior (9th ed.). Upper Saddle River, NJ: Prentice Hall.

Robinson, D., Perryman, S., \& Hayday, S. 2004. The drivers of employee engagement. Brighton, UK: Institute for Employment Studies.

Rubin, E. V. 2007. The role of procedural fairness in public personnel management: Empirical results from the Department of Defense. Journal of Public Administration Research and Theory, 19(1): 125-143.

Saks, A. M. 2006. Antecedents and consequences of employee engagement. Journal of Managerial Psychology, 21(6): 600-619.

Schaufeli, W. B., \& Bakker, A. B. 2004. Job demands, job resources and their relationship with burnout and engagement: A multi-sample study. Journal of Organizational Behavior, 25(3): 293-315.

Sobel, M. E. 1982. Asymptotic intervals for indirect effects in structural equations models. In S. Leinhart (ed.), Sociological methodology (pp. 290-312). San Francisco, CA: Jossey-Bass.

Somech, Anit. (2005). Directive versus participative leadership: two complementary approaches to managing school effectiveness. Educational Administration Quarterly, 41: 777-800.

Sonnentag, S. 2003. Recovery, work engagement, and proactive behavior: A new look interface between nonwork and work. Journal of Applied Psychology, 56(2): 518-528.

Strauss, G. 1977. Managerial practices. In J. R. Hackman \& J. L. Suttle (eds.), Improving life at work: Behavioral science approaches to organizational change (pp. 297363). Santa Monica, CA: Goodyear.

Tannenbaum, R., \& Schmidt, W. 1958. How to choose a leadership pattern. Harvard Business Review, 36 (March-April): 95-101.

Thibaut, J., \& Walker, L. 1975. Procedural fairness: A psychological analysis. Hillsdale, NJ: Erlbaum.

Thomson, A. M., \& Perry, J. L. 2006. Collaboration process: Inside the black box. Public Administration Review, 66: 20-32. 
US MSPB (Merit Systems Protection Board). 2008. Improving agency outcomes: The power offederal employee engagement. Washington, DC: Author.

US OPM (Office of Personnel Management). 2008. Results from the 2008 Federal Human Capital Survey. Washington, DC: Author.

Venkatraman, N. and Ramanujam, V. (1987). Measurement of Business Economic Performance: An Examination of Method Convergence. Journal of Management, 13: 109-122.

Wanous, J. P., \& Reichers, A. E. 1996. Estimating the reliability of a single-item measure. Psychological Reports, 78(2): 631-634.

\section{APPENDIX}

Table A1. M easures of Variables from Federal Human Capital Survey

\begin{tabular}{|c|c|c|}
\hline Variable & Questions & Response options \\
\hline $\begin{array}{l}\text { Employee } \\
\text { engagement }\end{array}$ & $\begin{array}{l}\text { 1. The people I work with cooperate to get the job done. } \\
\text { 19. I know how my work relates to the agency's goals and } \\
\text { priorities. } \\
\text { 33. I am held accountable for achieving results. }\end{array}$ & $\begin{array}{l}5=\text { strongly agree } \\
4=\text { agree } \\
3=\text { neither agree nor disagree } \\
2=\text { disagree } \\
1 \text { = strongly disagree }\end{array}$ \\
\hline $\begin{array}{l}\text { Organizational } \\
\text { performance }\end{array}$ & $\begin{array}{l}\text { M anagerial performance } \\
\text { 9. Overall, how good a job do you feel is being done by } \\
\text { your immediate supervisor/team leader? } \\
\text { Productivity } \\
\text { 15. The skill level in my w ork unit has improved in the } \\
\text { past year. } \\
\text { W ork quality } \\
\text { 10. How w ould you rate the overall quality of w ork done } \\
\text { by your w ork group? } \\
\text { Customer service orientation } \\
\text { 25. Employees are rewarded for providing high quality } \\
\text { products and services to customers. }\end{array}$ & $\begin{array}{l}\text { Questions } 9 \text { and } 10: \\
5=\text { very good } \\
4=\text { good } \\
3=\text { fair } \\
2=\text { poor } \\
1=\text { very poor } \\
\text { Questions } 15 \text { and } 25: \\
5=\text { strongly agree } \\
4=\text { agree } \\
3=\text { neither agree nor disagree } \\
2=\text { disagree } \\
1 \text { = strongly disagree }\end{array}$ \\
\hline $\begin{array}{l}\text { Participative leadership } \\
\text { support }\end{array}$ & $\begin{array}{l}\text { Delegation } \\
\text { 13. Supervisors/team leaders in my work unit provide } \\
\text { employees with the opportunities to demonstrate their } \\
\text { leadership skills. } \\
\text { 55. How satisfied are you with your involvement in } \\
\text { decisions that affect your work? } \\
\text { Empow erment } \\
\text { 24. Employees have a feeling of personal empow erment } \\
\text { with respect to work processes. }\end{array}$ & $\begin{array}{l}\text { Questions } 13 \text { and } 24: \\
5=\text { strongly agree } \\
4 \text { = agree } \\
3 \text { = neither agree nor disagree } \\
2 \text { = disagree } \\
1 \text { = strongly disagree } \\
\text { Question } 55: \\
5=\text { very satisfied } \\
4=\text { satisfied } \\
3=\text { neither dissatisfied nor } \\
\quad \text { satisfied } \\
2=\text { dissatisfied } \\
1 \text { = very dissatisfied }\end{array}$ \\
\hline
\end{tabular}




\begin{tabular}{|c|c|c|}
\hline Variable & Questions & Response options \\
\hline $\begin{array}{l}\text { Supportiveness of } \\
\text { organizational context }\end{array}$ & $\begin{array}{l}\text { 2. I am given a real opportunity to improve my skills } \\
\text { in my organization. } \\
\text { 3. I have enough information to do my job well. } \\
\text { 16. I have sufficient resources (for example, people, } \\
\text { materials, budget) to get my job done. } \\
\text { 18. My talents are used well in the workplace. } \\
\text { 50. Employees have electronic access to learning and } \\
\text { training programs readily available at their desks. } \\
\text { 51. My training needs are assessed. }\end{array}$ & $\begin{array}{l}5=\text { strongly agree } \\
4=\text { agree } \\
3=\text { neither agree nor disagree } \\
2=\text { disagree } \\
1=\text { strongly disagree }\end{array}$ \\
\hline Procedural fairness & $\begin{array}{l}\text { 22. Promotions in my work unit are based on merit. } \\
\text { 23. In my work unit, steps are taken to deal with a poor } \\
\text { performer who cannot or will not improve. } \\
\text { 44. Complaints, disputes, or grievances are resolved fairly } \\
\text { in my work unit. } \\
\text { 47. I can disclose a suspected violation of any law, rule, } \\
\text { or regulation without fear of reprisal. } \\
\text { 45. Arbitrary action, personal favoritism, and coercion for } \\
\text { partisan political purposes are not tolerated. } \\
\text { 46. Prohibited personnel practices (for example, illegally } \\
\text { discriminating for or against any employee/applicant, } \\
\text { obstructing a person's right to compete for employment, } \\
\text { know ingly violating veterans' preference requirements) } \\
\text { are not tolerated. }\end{array}$ & $\begin{array}{l}5=\text { strongly agree } \\
4=\text { agree } \\
3=\text { neither agree nor disagree } \\
2 \text { =disagree } \\
1=\text { strongly disagree }\end{array}$ \\
\hline Distributive fairness & $\begin{array}{l}\text { 27. Pay raises depend on how well employees perform } \\
\text { their jobs. } \\
\text { 28. Awards in my work unit depend on how well } \\
\text { employees perform their jobs. } \\
\text { 29. In my work unit, differences in performance are } \\
\text { recognized in a meaningful way. } \\
\text { 30. My performance appraisal is a fair reflection of my } \\
\text { performance. }\end{array}$ & $\begin{array}{l}5=\text { strongly agree } \\
4=\text { agree } \\
3=\text { neither agree nor disagree } \\
2=\text { disagree } \\
1=\text { strongly disagree }\end{array}$ \\
\hline
\end{tabular}

Table A2. M easures of Control Variables

\begin{tabular}{l|l|l}
\hline Variable & M easures & Data source \\
\hline $\begin{array}{l}\text { Type of policy } \\
\text { responsibility }\end{array}$ & $\begin{array}{l}\text { Three dummy variables (1, 0)-regulatory, distributive, } \\
\text { and redistributive agencies }\end{array}$ & $\begin{array}{l}\text { 2008 Congressional Quarterly's } \\
\text { Federal Regulatory Directory } \\
\text { Regulatory Policy and the } \\
\text { Social Sciences, edited by } \\
\text { Roger G. Noll (1985) }\end{array}$ \\
\hline Institutional location & $\begin{array}{l}\text { Dummy variable (1 for executive branch, 0 for } \\
\text { independent agency) }\end{array}$ & Central Personnel Data File \\
\hline Organizational size & Natural logarithm of the number of full-time employees & Central Personnel Data File \\
\hline Organizational age & Year the agency was established & Agency Web sites \\
\hline Organizational tenure & Average tenure of full-time employees in an agency & Central Personnel Data File \\
\hline Task professionalization & $\begin{array}{l}\text { Proportion of employees in professional and administrative } \\
\text { occupational categories }\end{array}$ & Central Personnel Data File \\
\hline
\end{tabular}

